8

\title{
SOCIAL CONSTRUCTIONISM THEORY
}

\section{Constructing the user experience of workplace}

\author{
Kaisa Airo*
}

\section{Background}

Peter Berger and Thomas Luckmann developed the theory of social construction of reality at the end of the 1960s (1966). It accelerated the narrative turn in social sciences, which pushed the research to concentrate more on how knowledge and meaning are constructed than on what actually is true. Issues such as power, discrimination, deviance, crime and media became popular topics of interest, and the focus shifted from statistical research to socio-linguistics and the use of language in a cultural sense.

The basic principle of social constructionism is that many of the things we perceive as objective truths are not but are constructed culturally or socially. For instance, gender roles, marriage or values are more culturally defined than factually there. Since the 1980 s social sciences have been interested in interpreting this objective reality from a critical point of view. Studies have been labelled for example as critical psychology, discourse analysis, deconstruction or critical sociology. However, all of these perspectives can be categorised under the vast umbrella of social constructionism theory (Burr, 2015).

Social constructionism refers to theory on reality and knowledge creation (see also Chapter 22 on knowledge creation theory), thus in principle it is ontological theory on what we consider real and true. On the other hand, it differs from philosophical theories of knowledge in a sense that it is interested in social processes of knowledge creation rather than on objective truth (Berger \& Luckmann, 1966).

Social constructionism is based on the idea that language does not mirror reality; rather, it constitutes it (Fairhurst \& Grant, 2010). It states that reality is both produced and interpreted in a social context through language and communication. Therefore, knowledge is profoundly social (Davenport \& Prusak, 2000). Not just all the abstract concepts but also all the material objects are then defined, valued and ultimately experienced in a social process. From the perspective of social constructionism, studying different aspects of language is crucial when aiming at understanding reality. From a social constructionism point of view, language is any kind of symbolic system that can be interpreted, not just ethnic or verbal language.

Social constructionism is based on two principles. The first emphasizes the role of language in constructing knowledge and the second elaborates the social nature of knowledge creation. The fundamental principles are overlapping since one would not exist without another, but they

*Corresponding author: kaisa.airo@laurea.fi 
do differ conceptually, as social networks are the nodes of human behaviour and language is the mean between the subjects.

Socially constructed workplace literature often concentrates on organisational theory. In management and organisation research, discursive articles discuss the general organisation communication theory (Bisel, 2009; Sillince, 2007) or segmented groups in work such as mothers or the elderly (e.g. Medved \& Kirby, 2005). In addition, social constructionism concentrates to workplace phenomena and analysing workplaces also as spatial language (O’Brien, 2020).

Social constructionism is intertwined with other similar sociolinguistic and discursive perspectives and methods. In this chapter the tradition of discourse analysis is presented. Discourse analysis refers to a number of different perspectives in analysing language. There are multiple usages and interpretations of the method, which can also be seen as a theory in itself. However, the term discourse analysis was introduced by Harris in the 1950s. In Britain in the 1970s Mulkay and his students developed the method further (Mulkay, Potter, \& Yearley, 1983). The term discourse is defined by Michel Foucault in The Archaeology of Knowledge (1969). More precisely, Foucault developed the concept of discourse by defining analysis as an archaeological method, which refers to the layered nature of language. By this, Foucault (1969) means that reality, as we perceive it, is a product of an ongoing discursive game in which defining concepts is the basic strategy of claiming a power position. Language both reflects and produces social reality.

The other perspective and method is narrative analysis, which accordingly claims that people's experience and memory are built upon stories and storyline structures. Hence analysing the topics of interest, such as actors, stages and goals, could be reconstructed in stories (Labov \& Waletzky, 1967).

\section{Applicability to workplace}

Workplace management research has not applied social constructionism extensively. In this chapter the theory and its implications are discussed based on the author's doctoral dissertation (Airo, 2014) with the addition of current literature, which suggests that the social construction is still a rare perspective in workplace management.

In workplace management research, social constructionism is mostly applied in researching organisational behaviour or employee experience, rather than the space or place itself. However, according to social constructionism, the built environment, including workspaces in their physical sense, is also the institutionalised object of a social process. This environment is experienced and perceived in a discursive process. Ideals, meanings and cultural assumptions govern the design, use and management of any built space. Ideals, meanings and cultural assumptions are overall discursive concepts, that is, they are derived from language. The built environment is not only constructed from physical things, it is also designed, understood and experienced discursively.

Markus and Cameron (2002) claim that the language used when speaking and writing about the built environment plays a significant role in shaping the environment and our responses to it. Additionally, they emphasise the idea that although the buildings themselves do not have a discursive form, people using them use language in interpreting the environment. People who design, build and talk about buildings always have an agenda, which is shown in the way buildings are designed, valued and used.

Socially constructed space refers both to the production of actual space and to our perception and ultimately the experience of the space. This process is elaborated through habitualised institutions, verbal language and visual symbols. The topic of space is considered a somehow indifferent attribute in constructing the concept of workplace, which is often seen as a network of social relationships rather than a tangible space with meaning. The workplace is not merely 
an activity container (Hillier \& Hanson, 1984) for paid work, but contains representations of all other major social places in contemporary society. This means that workplace reflects social status and organisation rather than just functions as a neutral stage for working. Cairns (2003) emphasizes, like other scholars before him, that the physical stage of the workspace becomes a place once it is occupied by people. Once it is occupied by people, it becomes a social construction, in which language plays a significant role.

Workplace phenomena such as bullying, change resistance (Airo, Rasila, \& Nenonen, 2012; Bryant, 2003, 2006; Jørgensen, 2004), contradiction (Whittle, Mueller, \& Mangan, 2008), identity construction (Holmes, 2005) and leadership (Fairhurst, 2008) have been studied using a discursive approach. Tracy, Lutgen-Sandvik and Alberts (2006) have studied workplace bullying using narrative interviews to reveal the metaphors used when describing the distress of bullying. Miller, Considine and Garner have used workplace narratives as a resource to map the terrain of workplace emotions (2007). Sonenshein (2006) has studied the manner in which individuals shape the meaning of social structure while using intentionally different language in private discussions and public discussion of issues. However, social constructionistic studies, combining both the physical nature and the social processes of workplace, are quite rare.

In recent decades, many organisations have begun to take a closer look at the workplace's strategic significance for organisational performance (Skogland \& Hansen, 2017). There is still confusion about the definition of workplace because the concepts of place and space are ambiguous. Gieryn explains how places differ from spaces by saying, "Space is what place becomes when the unique gathering of things, meanings, and values are sucked out" (Gieryn, 2000, p. 463). Spaces thus are physical entities, which lack all of the qualities stated by the ground rules, such as meaning, physical boundaries, an association with meaningful things and specific locations, and finitude. In this sense, workspace, for instance, is not just space, though neither it is a place, because place can be defined based on the aforementioned ground rules. Still, workspaces have some of the qualities of places. Workspace is considered the physical space in which the work takes place, and workplace is the social and organisational place where employees work (Price, 2012). However, workspace includes a gathering of things, meaning and value. Thus, it is not mere physical space. Rather, workplace also implies an organisational, abstract place where one can go, without going to a particular workspace. Thus, workplace is not as physical as the definition of place, which includes, for instance, a specific location. Conversely, workspace is more than just physical space. Lefebvre (1991) claims that when investigating space, it is more important to focus on the ways that space is categorised than to focus on the space itself, because space itself is only an abstract entity full of nothing. It becomes understandable only through restrictions and borders; in other words, the way that space is defined.

One stream of social constructionistic theories in organisations and the built environment focuses on how physical artefacts (including space) are used as a means of communication and role construction. For instance, Frers (2009) has used discourse analysis in demonstrating the way that the material world reaches into social interactions and consequently fills in mental maps of the social world with physical details. Sparkes, Brown and Partington have taken a similar perspective when studying how space can be and is used as a mean of constructing social identity among university students (2010). In addition, Ainsworth, Grant and Iedema (2009) have used discourse analysis to prove that the spatial imagery has a significant role in constructing the manager's identity. Managers used the concepts of mobility and locality and the idea of a social space to describe their role in the organisation. The concept of moving freely and accessing information was considered a symbol of power, whereas getting stuck or between the walls was considered as losing power. Thus, spatial imagery places a discursive function in describing the assumed position in an organisation. 
The use of discursive methods combining all of the attributes of workplace management, (a) management, (b) spatial issues and (c) discursive methods, seems to be non-existent (Airo, 2014). The challenges of multidisciplinary issues seem to hinder both disciplines. Still, everyday reality is neither partial nor segmented but instead is a holistic combination of the social and the physical. That is, because workplaces are social constructions, they are also physical entities that are connected to social behaviour. Because the academic tradition of workplace management is not only new but also focused on practical applications, the ontological and epistemological premises of the field are ambiguous (Cairns, 2003).

\section{Methodology}

Social constructive methods concentrate on language and more so the discursive structure of language rather than, for example, grammar. Social constructionist methods are not either qualitative or quantitative by nature. This is because they do not seek to find coherent synthesis. At least discourse analysis does not. The methods only point out that objective matter of facts are rarely matter of facts as such but instead are socially constructed. However, from the methodological point of view, social constructionistic methods resemble qualitative methods, which often enable multiple possible interpretations of the same data depending on the intuition, insights and scientific imagination of a researcher, perceiving all such interpretations to be potentially meaningful (Eriksson \& Kovalainen, 2008). This also applies to the discursive approach, in which a researcher's interpretations play a profound role. Accordingly, the aim of this type of methodology is more to understand how something works rather than what it truly is. Thus, the results are not ripe for generalisation. Two most typical discursive methods in social constructionism are discourse and narrative analysis, which both concentrate on deconstructing language.

Discourse can be narrowly defined as the practices of talking and writing (Woodilla, 1998). More precisely, discourse means the relations of talking, writing or otherwise producing a cultural text, which can also be a picture, photograph, artefact and so forth. Text is the basic unit of data for discourse analysis. It is also essential to acknowledge that texts are not meaningful individually but only through their interconnection with other texts (Phillips \& Hardy, 2002). Discourse is often confused with ordinary communication (Jones, 2005); however, discourse analysis examines the implicit cultural structures of communication rather than the explicit content of that communication.

Discourse analysis often aims to reveal underlying messages bound to culturally dependent values. By deconstructing these values, the researcher is able to find potentially hidden agendas behind the message of the subject. Discourse analysis and critical discourse analysis are traditionally used to study power relations within a society (Fairclough \& Wodak, 1997; Starks \& Brown Trinidad, 2007). A typical object of discourse analysis would be a politician's speech or a media text. Recently, discourse analysis has been used to study the ways in which people give meaning to their existing reality (e.g., work, parenting, gender, etc.) (e.g., Ashcraft, 2007).

Narrative analysis is connected to the idea of social constructionism, which means that our experiences are constructed in an ongoing social process, which embodies our subjective history and our present interactions with our environment. Narrative analysis was developed by Labov and Waletzky (1967), who define narrative as a story that has both a clear beginning and a clear end. Although the world and tangible reality exist all the time, everywhere, mental processes and verbal output are always constructed in a form of a narrative - a story. Thus, analysing the structure of the narratives that people present may reveal something possibly hidden about their experience of a subject. 
Rymes explains that in a narrative analysis, it is important to recognise that narrative in itself is not a portal to experience. At least, narrative is not a direct portal. Instead, narrative, in any form and by necessity, always involves narrating to someone and in some context. This means that narrative analysis depends on speech acts, which are inevitably related to speaking, context, meaning and subjective descriptions (2010). In other words, narrative analysis is concerned about the positioning of events, things and subjects rather than the stories themselves.

Social constructionism in research should be applied more in studying the language of the built environment and the language of the users of the space. In addition, the language that is used when publicly discussing space is very fruitful in analysing the attitudes, power structures or roles of different actors in the field of workplace management. For instance, Airo analysed the discourses of media about open-plan offices and claimed that our attitudes are highly influenced by words used in news reporting and discussions (2014). This kind of study would benefit from revealing the 'tone of voice' used in political and business-driven decisions.

The symbolism of space itself is also very useful and certainly an understudied topic in workplace and facility management. This perspective could benefit from the theories about nudging and deaf spaces as well as studies of visual language and usability. The visual language is complemented with the verbal language used. Studying discourses of change management might reveal hidden agendas of the different parties concerned with workplace change.

\section{Limitations}

A social constructionist approach in workplace management is still rare and ambiguous. Research on management and organisational behaviour acknowledges the perspective to some extent, but the research on the built environment seems to lack such a paradigm. It seems that journals that concentrate on social and cultural studies overlook the subjects of business and the workplace, whereas journals on management and the built environment do not extensively publish papers with discursive/socially constructive perspectives and/or methodology.

Although research based on social construction is often motivated by practical problems, it does not give recommendations or practical tools solving such issues. Additionally, theories developed based on socially constructed principles are in danger of becoming self-explaining. In other words, the results can be seen as circular, especially because they, as other qualitative methods, are subjective, since the researcher him/herself is bound to the empirical data he/she interprets and describes.

Another limitation in social constructionism is the relationship between empirical data and the theory. They both explain one another, which can conclude to the circular thinking, in which it is impossible to say which initiated the other. For instance, the general discourse on social construction itself has become an explaining force, but also a producing force of social institutions, such as modern school system or the media. This can be an ontological problem, but it is also an empirical example on how the philosophy of social constructionism embodies to practical reality.

\section{Applicability to practise}

Social constructionism does not take a stand on tangible reality. On the other hand, some practical problems are due to social construction. For instance, if certain problems are often discussed they might be perceived as problems, although they have not been perceived as such earlier. This process can work the other way as well. Verbalising issues influences the way they are perceived. 
Thus, social constructionism does not provide answers, but the pure existence of the perspective might change the way we perceive knowledge, which influences the way things really are.

Regardless of the limitations of social constructionism, facility managers should pay more attention to the communication strategies taking place in a workplace context. In order to develop a sufficient communicational strategy, one should understand how users communicate about the space. One should be aware of current sensemaking processes in order to develop and manage the facilities in the future. End users might pay attention to something completely different than what the managers are concentrating on. Additionally, the users and the manager consider issues as matters of facts, although they are socially constructed. For instance, the enclosed office is considered traditional, although in fact it is not as traditional a working space as an open-plan layout. Using words such as traditional gives a certain discursive value to the space, which in the end is just there. What we consider objective truth might be a matter of people constructing meaning in the social network. That is, using language. The whole reality the users experience is constructed with language.

All the stakeholders in workplace management, from designers to facility managers, should pay more attention to physical language, that is, the language of the space itself. People draw conclusions out of physical hints. This can be seen in research about the usability of workplaces or about event management. Physical language has been discussed through the concept of the deaf space. Sign language is based on visual and spatial attributes and is not verbal as such. The discussion about deaf architecture revolves around the idea that workplaces actually speak and communicate in their own right (O'Brien, 2020). Even though this is often discussed in the context of disability and inclusive environment, the thought of communicating environments could be applied more extensively such as in nudging environments or enhancing the employee experience in any workplace. The narratives and the symbolism of the space have a crucial role in navigation and sense of aesthetics. How users interpret physical hints is highly connected to socially constructed reality. Understanding physical language might make actual economic difference in designing more efficient facility services from cleaning to catering.

Undoubtedly, language about spaces is still an unknown territory, and as such it should be more extensively researched and applied. This should be acknowledged among all of the stakeholders in the fields of facility management and the built environment. Managing space not only as a physical asset but also as a source of conversation - is important. The workplace discourse is not disconnected: it takes place in relation to space and is an important channel to deepen the understanding not only of users' workplace experience, but also in designing, constructing or managing the workspace and -place.

\section{Further reading}

- Airo, K. (2014). Workplace and language - Constructing the user experience of office space. Espoo: Aalto Publications.

- Ajtony, Z., \& Pieldner, J. (2013). Discourses of space. New Castle upon Tyne: Cambridge Scholars Publishing.

- Berger, P., \& Luckmann, T. (1966). The social construction of reality: A treatise in the sociology of knowledge. Garden City, NY: Anchor.

- Burr, V. (2015). Social constructionism. London: Routledge.

- Cameron, D., \& Markus, T. (2003). Words between spaces. New York, NY: Routledge.

- Ryan, M., Foote, K., \& Azaryahu, M. (2016). Narrating space/Spatializing narrative: Where narrative theory and geography meet. Columbus, $\mathrm{OH}$ : The Ohio State University Press. 


\section{References}

Ainsworth, S., Grant, D., \& Iedema, R. (2009). 'Keeping things moving': Space and the construction of middle management identity in a post-NPM organization. Discourse and Communication, 3(1), 5-25. https://doi.org/10.1177/1750481308098762

Airo, K. (2014). Workplace and language: Constructing the user experience of office space. Espoo: Aalto Publications. Retrieved from http://urn.fi/URN:ISBN:978-952-60-5954-9

Airo, K., Rasila, H., \& Nenonen, S. (2012). Speech as a way of constructing change in space: Opposing and conforming discourses in workplace change process. Facilities, 30, (7/8), 289-301. https://doi. org/10.1108/02632771211220095

Ashcraft, K. L. (2007). Appreciating the 'work' of discourse: Occupational identity and difference as organizing mechanisms in the case of commercial airline pilots. Discourse and Communication, 1(1), 9-36. https://doi.org/10.1177/1750481307071982

Berger, P., \& Luckmann, T. (1966). The social construction of reality: A treatise in the sociology of knowledge. Garden City, NY: Anchor.

Bisel, R. S. (2009). On a growing dualism in organizational discourse research. Management Communication Quarterly, 22(4), 614-638. https://doi.org/10.1177/0893318908331100

Bryant, M. (2003). Persistence and silence: A narrative analysis of employee responses to organisational change. Sociological Research Online, 8(4), 246-258. https://doi.org/10.5153/sro.853

Bryant, M. (2006). Talking about change: Understanding employee responses through qualitative research. Management Decision, 44(2), 246-258. https://doi.org/10.1108/00251740610650229

Burr, V. (2015). Social constructionism. London: Routledge.

Cairns, G. (2003). Seeking a facilities management philosophy for the changing workplace, Facilities, 21(5/6), 95-105. https://doi.org/10.1108/02632770310476705

Davenport, T. H., \& Prusak, L. (2000). Working knowledge: How organizations manage what they know. Boston, MA: Harvard Business Press.

Eriksson, P., \& Kovalainen, A. (2008). Qualitative methods in business research. London: SAGE Publications.

Fairclough, N. L., \& Wodak, R. (1997). Critical discourse analysis. In T. A. van Dijk (Ed.), Discourse studies: A multidisciplinary introduction. Discourse as Social Interaction, 2 (pp. 258-284). London: Sage.

Fairhurst, G. T. (2008). Discursive leadership: A communication alternative to leadership psychology. Management Communication Quarterly, 21(4), 510-521. https://doi.org/10.1177/0893318907313714

Fairhurst, G., \& Grant, T. (2010). Social construction of leadership: A sailing guide. Management Communication Quarterly, 21(4), 171-210. https://doi.org/10.1177/0893318909359697

Foucault, M. (1969). The archaeology of knowledge. London and New York: Routledge.

Frers, L. (2009). Space, materiality and the contingency of action: A sequential analysis of the patient's file in doctor-patient interactions. Discourse Studies, 11(3), 285-303. https://doi.org/10.1177/1461445609102445

Gieryn, T. F. A. (2000). Space for Place in Sociology. Annual Review of Sociology, 26, 463-496. https://doi. org/10.1146/annurev.soc.26.1.463

Hillier, B., \& Hanson, J. (1984). The social logic of space. Cambridge: Cambridge University Press.

Holmes, J. (2005). Story-telling at work: A complex discursive resource for integrating personal, professional and social identities. Discourse Studies, 7(6), 671-700. https://doi.org/10.1177/1461445605055422

Jones, D. (2005). Spot the difference: Discourse in organizational communication, organizational studies, and workplace sociolinguistics. Management Communication Quarterly, 19(2), 288-298. https://doi.org/10.11 $77 / 0893318905278537$

Jørgensen, K. M. (2004). Creating value-based collaboration: Life forms and power in a change project, Management, 7(3), 85-107. Retrieved from www.cairn.info/journal-management-2004-3-page-85.htm

Labov, W., \& Waletzky, J. (1967). Narrative analysis: Essays on the verbal and visual arts, ed. J. Helm, $12-44$. Seattle: U. of Washington Press. Reprinted in Journal of Narrative and Life History, 7, 3-38. https://doi. org/10.1075/jnlh.7.02nar

Lefebvre, H. (1991). The production of space. Oxford: Blackwell Publishing.

Markus, T. A., \& Cameron, D. (2002). The words between the spaces: Buildings and language. London/New York: Routledge.

Medved, C. E., \& Kirby, E. L. (2005). Family CEOs: A feminist analysis of corporate mothering discourses. Management Communication Quarterly, 18(4), 435-478. https://doi.org/10.1177/0893318904273690

Miller, K. I., Considine, J., \& Garner, J. (2007). Let me tell you about my job: Exploring the terrain of emotion in the workplace. Management Communication Quarterly, 20(3), 231-260. https://doi.org/10.1177/089331 8906293589 


\section{Kaisa Airo}

Mulkay, M., Potter, J., \& Yearley, S. (1983). Why an analysis of scientific discourse is needed. In Science observed: Perspectives on the social study of science (pp. 171-203). London: Sage.

O'Brien, D. (2020). Negotiating academic environments: Using Lefebvre to conceptualise deaf spaces and disabling/enabling environments. Journal of Cultural Geography, 37(1), 26-45. https://doi.org/10.1080/ 08873631.2019 .1677293

Phillips, N., \& Hardy, C. (2002). Discourse analysis: Investigating processes of social construction. Thousand Oaks, CA: Sage Publications.

Price, I. (2012). The social construction of FM communities. In I. Price \& K. Alexander (Eds.), Managing organisational ecologies: Space, management and organisation. New York: Routledge.

Rymes, B. (2010). Why and why not? Narrative approaches in the social sciences. Narrative Inquiry, 20(2), 371-374. https://doi.org/10.1075/ni.20.2.07rym

Sillince, J. A. (2007). Organizational context and the discursive construction of organizing. Management Communication Quarterly, 20(4), 363-394. https://doi.org/10.1177/0893318906298477

Skogland, M. A. C., \& Hansen, G. K. (2017). Change your space, change your culture: Exploring spatial change management strategies. Journal of Corporate Real Estate, 19(2), 95-110. https://doi.org/10.1108/ JCRE-07-2016-0024Sonenshein, S. (2006). Crafting social issues at work. Academy of Management Journal, 49(6), 1158-1172. https://doi.org/10.5465/amj.2006.23478243

Sparkes, A., Brown, D. H. K., \& Partington, E. (2010). The jock body and the social construction of space: The performance and positioning of cultural identity. Space and Culture, 13(3), 333-347. https://doi. org/10.1177/1206331210365288

Starks, H., \& Brown Trinidad, S. (2007). Choose your method: A comparison of phenomenology, discourse analysis, and grounded theory. Qualitative Health Research, 17(10), 1372-1380. https://doi.org/10.1177/ 1049732307307031

Tracy, S. J., Lutgen-Sandvik, P., \& Alberts, J. K. (2006). Nightmares, demons, and slaves: exploring the painful metaphors of workplace bullying. Management Communication Quarterly, 20(2), 148-185. https:// doi.org/10.1177/0893318906291980

Whittle, A., Mueller, F., \& Mangan, A. (2008). In search of subtlety: Discursive devices and rhetorical competence. Management Communication Quarterly, 22(2), 99-122. https://doi.org/10.1177/08933189 08318515

Woodilla, J. (1998). Workplace conversations: The text of organizing. In D. Grant, T. Keenoy, \& C. Oswick (Eds.), Discourse and organization (pp. 31-50). London: Sage. 